Dr PETAR DRAGIŠIĆ, viši naučni saradnik

Institut za noviju istoriju Srbije

Beograd, Republika Srbija

UDK 314.15(=163.42)"1981/1983"(093.2)

petar.dragisic@gmail.com

327.88::323.28(100)"1968/1980"(093.2)

327(497.1)"196/198"(093.2)

originalan naučni rad / original scientific paper

primljeno / received: 4. 12. 2019.

prihvaćeno / accepted: 20. 5. 2020.

https://doi.org/10.29362/ist20veka.2020.2.dra.203-218

\title{
HRVATSKA POLITIČKA EMIGRACIJA I JUGOSLAVIJA POČETKOM OSAMDESETIH GODINA. PRIPREME ZA ZAVRŠNI OBRAČUN
}

APSTRAKT: $U$ članku su prikazani osnovni elementi organizovanja $i$ delovanja hrvatske političke emigracije početkom osamdesetih godina prošlog veka. Akcenat je stavljen na formiranje i delovanje dve najznačajnije organizacije hrvatske emigracije u tom periodu - Hrvatskog narodnog vijeća i Hrvatskog državotvornog pokreta. Izneti su detalji o načinima njihovog delovanja, a funkcionisanje hrvatske emigracije stavljeno je u širi međunarodni kontekst. Rad je nastao analizom sekundarnih izvora i neobjavljene arhivske građe.

KLJUČNE REČI: Hrvati, emigracija, Hrvatsko narodno vijeće, Mate Meštrović, Jugoslavija

Tokom manje od pola veka svog postojanja socijalistička Jugoslavija je bila konfrontirana sa brojnim spoljnim i unutrašnjim izazovima. U faktore koji su u priličnoj meri doprinosili destabilizaciji Jugoslavije ubrajamo i političku emigraciju, u okviru koje je poseban radikalizam ispoljavala hrvatska politička emigracija. U hrvatskom emigrantskom miljeu delovalo je više organizacija, od kojih su do kraja sedamdesetih godina prošlog veka posebno aktivne bile Hrvatski oslobodilački pokret, Hrvatski narodni odpor, Hrvatski narodni odbor i Hrvatsko revolucionarno bratstvo. Organizacije hrvatske političke emigracije su se sa jugoslovenskim poretkom obračunavale propagandnim aktivnostima, ali i nasilnim udarima na jugoslovenske interese u zemlji i izvan nje. ${ }^{1}$

\footnotetext{
${ }^{1} \mathrm{O}$ tome opširnije u: Petar Dragišić, Ko je pucao u Jugoslaviju? Jugoslovenska politička emigracija 1968-1980 (Beograd: Institut za noviju istoriju Srbije, 2019); Mario Jareb, „Hrvatska politička emigracija 1928-1990“, Hrvatska politika u XX stoljeću, ur. Ljubomir Antić (Zagreb: Matica hrvatska, 2006), 307-336; Srđan Cvetković, „Terorizam i jugoslovenska politička emigracija“, Istorija 20. veka, br. 2, (2014), 171-197; Bože Vukušić, Tajni rat UDBE protiv hrvatskoga iseljeništva (Zagreb: Klub hrvatskih povratnika iz iseljeništva, 2002); Petar Dragišić, "Operation Phoenix in Yugoslavia in the Summer of 1972 and Yugoslav-Austrian Relations", Tokovi istorije, br. 3, (2018), 87-106; Bojan Dimitrijević, „Istorijski aspekti terorizma u Srbiji“, Istorija 20.
} 
Posebno uticajna organizacija hrvatske političke emigracije krajem sedamdesetih i početkom osamdesetih godina bilo je Hrvatsko narodno vijeće (HNV). Temelji za konstituisanje ove uticajne organizacije hrvatske političke emigracije postavljeni su sredinom sedamdesetih godina. Iz izvora jugoslovenske policijske provenijencije proizilazi da je za osnivanje HNV od velike važnosti bio kongres hrvatske političke emigracije u Torontu 1974. godine, na kojem su učestvovali predstavnici preko dvadeset hrvatskih emigrantskih grupa. $\mathrm{Na}$ ovom velikom skupu hrvatske emigracije formirano je Hrvatsko narodno vijeće, kao i izvršni odbor ove nove organizacije hrvatskih političkih emigranata. Nakon ovih prvih koraka u formiranju HNV-a organizacija je nastavila sa sopstvenim institucionalnim razvojem, odnosno sa konstituisanjem filijala $u$ brojnim emigrantskim centrima na Zapadu. ${ }^{2}$

Prema saznanjima jugoslovenskih posmatrača prilika u hrvatskoj političkoj emigraciji, HNV nije uspelo da obuhvati celokupan hrvatski emigrantski milje. Zamišljeno kao krovna organizacija Hrvata u egzilu HNV nije u svoj sastav uključilo Hrvatsku seljačku stranku, kao i Hrvatski oslobodilački pokret (HOP). HOP se, naime, kao radikalna organizacija hrvatske političke emigracije, protivio insistiranju HNV-a na političkim sredstvima u borbi za realizaciju svojih ciljeva. U Beogradu se procenjivalo da je Vijeće početkom osamdesetih godina imalo blizu 5.000 članova, raspoređenih kako u Zapadnoj Evropi, tako i $\mathrm{u}$ prekookeanskim centrima hrvatske dijaspore. Rukovodstvo organizacije je, posle kratkog perioda ,prolećarskog“ liderstva (Bruno Bušić i Franjo Mikulić), prešlo u ruke Mate Meštrovića i Mirka Vidovića. ${ }^{3}$ HNV je, prema svedočenju Mate Meštrovića, nastalo dogovorom četiri velike organizacije hrvatske političke emigracije: odmetničkog Hrvatskog oslobodilačkog pokreta, čiji je lider bio ustaški ministar Vjekoslav Vrančić, Hrvatskog narodnog odbora, na čelu sa Ivanom Jelićem (bratom tada već pokojnog Branka Jelića), Hrvatske republikanske stranke, te Hrvatskog narodnog odpora (organizacije koju je osnovao Vjekoslav Maks Luburić). ${ }^{4}$

Sabor HNV-a u Londonu 1980. godine označio je pobedu umerene struje u okviru ove organizacije Hrvata u egzilu. Meštrović je bio eksponent upravo te manje radikalne grupacije, dok su se na drugoj, ekstremnijoj strani našli sledbenici Brune Bušića, ubijenog 1978. godine u Parizu. Dve decenije kasnije o tome je Meštrović svedočio na sledeći način: „Na Saboru Hrvatskog narodnog vijeća 1980. u Londonu dvije struje sukobile su se oko pitanja: kako uspostaviti neovisnu hrvatsku državu? Mirnim, demokratskim putem, ili pak borbom i tero-

veka, br. 1, (2008), 131-140; Радован Калабић, Српска емиграција. Прилози за историју српског исељеништва (1830-1992) - друго, допуњено издање (Београд/Њујорк: б. и., 1995); Branko Pavlica, Antijugoslovenska aktivnost neprijateljske emigracije u SR Nemačkoj (1951-1984) (Smederevo: Naš glas, 1990).

${ }^{2}$ Arhiv Jugoslavije (AJ), fond 837, Kabinet Predsednika Republike, II-5/d, Informacija Službe državne bezbednosti (Iz biltena SSUP-a br. 73), 6. jun 1975.

${ }^{3}$ P. Dragišić, Ko je pucao u Jugoslaviju?, 43-45.

${ }^{4}$ Mate Meštrović, U vrtlogu hrvatske politike. Kazivanje Peri Zlataru (Zagreb: Golden marketing, 2003), 226. 
rom? Umjereniji, a njihovu tezu zastupao sam i ja, bili su za to da se ne oslanja na tradiciju NDH, nego da ju treba što više minimizirati. Dr. Vjekoslav Vrančić, koji je na Sabor doleteo iz Buenos Airesa, govorio je pametno: kako je prošlo vrijeme ustašovanja i kako nije uputno slaviti Antu Pavelića. A Vrančić je bio istaknuti ustaški prvak (...) Shvatio je da su ustaštvo i NDH u slobodnome svijetu neprihvatljivi i kompromitirani (...) Nerealni tvrdokorni program zastupali su istomišljenici onda već pokojnoga Brune Bušića, koji je sanjarski plovio oblacima i vatreno pisao da se jedino revolucionarnim akcijama u domovini i u emigraciji možemo izboriti za slobodnu i neovisnu Hrvatsku. “5

HNV se, dakle, okrenulo političkim metodama borbe za hrvatsku nezavisnost. Na kongresu ove organizacije 1982. godine u Torontu je, prema jugoslovenskim obaveštajnim saznanjima, ,istaknuta borba za nezavisnu Hrvatsku svim sredstvima, a protiv ove i bilo koje druge Jugoslavije“. Pri tom se insistiralo na ,propagandno-subverzivnim metodima borbe“, ali se, prema jugoslovenskim procenama, HNV protiv terora „samo deklarativno“ izjašnjavalo. U okviru političke kampanje za hrvatsku nacionalnu emancipaciju HNV je na pomenutom kongresu u Torontu predvidelo i lobiranje za hrvatsku stvar, odnosno ,upoznavanje svetske javnosti sa nezadovoljavajućim položajem Hrvata u Jugoslaviji i inostranstvu“. U okviru kampanje lobiranja HNV se, prema saznanjima jugoslovenskih vlasti, obraćalo „državnicima Zapada, Istoka i trećih zemalja“, „tražeći pomoć i nudeći ustupke“. Kontakti su, prema jednom dokumentu Službe za istraživanje i dokumentaciju Saveznog sekretarijata za inostrane poslove (SID), ostvarivani ne samo pismenim putem, već i neposredno, pa je organizacija došla do jednog broja prilično uticajnih ličnosti na Zapadu. U SAD je HNV uspelo da dođe do jednog broja kongresmena i senatora, pri čemu je vršen pritisak na Kongres u cilju pokretanja debate o kršenju ljudskih prava u Jugoslaviji. Pored toga, HNV je u Švedskoj ,,pridobilo“ jednog konzervativnog poslanika, a u Belgiji i Saveznoj Republici Nemačkoj ostvareni su kontakti sa liberalnim poslanicima Evropskog parlamenta. Mirko Vidović je, isticalo se u dokumentu SID-a, posetio i sedište Socijalističke partije Francuske (doduše, navedeno je da se ta informacija proveravala). U SR Nemačkoj i Italiji Hrvatsko narodno vijeće je, pretpostavljalo se u Beogradu, stupilo u vezu sa pojedinim predstavnicima tamošnjih demohrišćanskih partija. Pored toga, organizacija se obraćala i uticajnim međunarodnim organizacijama (UN, Evropski parlament, KEBS, Amnesty International i dr.), vodeći ,kampanju za ljudska prava u Jugoslaviji““. U tom smislu posebnu kampanju HNV je vodilo u Švedskoj i Kanadi u prilog Marka Veselice i Franje Tuđmana, koji su tada u Jugoslaviji izdržavali zatvorske kazne. Jedan od pravaca propagandne kampanje Hrvatskog narodnog vijeća protiv Jugoslavije bio je usmeren i na pokušaje lobiranja kod vodećih zemalja Zapada da se Jugoslaviji uskrate kreditni aranžmani. ${ }^{6}$

\footnotetext{
${ }^{5}$ Isto, $185-186$.

${ }^{6}$ AJ, fond 803, Predsedništvo SFRJ, f-1782, Savezni savet za zaštitu ustavnog poretka (materijal za 6. sednicu Saveta), Savezni sekretarijat za inostrane poslove - Služba za istraživanje i dokumentaciju, Antijugoslovenska aktivnost tzv. Hrvatskog narodnog vijeća, 14. oktobar 1982.
} 
HNV je, osim lobiranja u visokim krugovima međunarodne politike, svoje propagandne aktivnosti usmeravalo i prema nižim stratumima hrvatske emigracije, odnosno prema Hrvatima na radu u inostranstvu. Osim toga, početkom osamdesetih godina primetno je bilo i nastojanje da se snažnije deluje u samoj Jugoslaviji, pa je u tu svrhu u okviru Hrvatskog narodnog vijeća konstituisan „Ured za veze sa domovinom“ koji je, prema podacima SID-a, trebalo da funkcioniše kao „dvosmerni propagandni kanal“. U Beogradu se smatralo da je takva orijentacija HNV-a prema Jugoslaviji bila posledica uverenja ove emigrantske organizacije da će presudan faktor u realizaciji hrvatskog nacionalnog programa biti ne Hrvati u egzilu već „opozicione snage“ u samoj Jugoslaviji/Hrvatskoj, „koje će na etničkom tlu doneti odluku u prilog stvaranja nezavisne države Hrvatske“. ${ }^{\text {? }}$

Sredinom novembra 1982. Služba za istraživanje i dokumentaciju došla je do informacije da je HNV otvorilo urede u Parizu i Otavi, a da je odlučeno da se kancelarije otvore i u nekoliko velikih gradova u Sjedinjenim Američkim Državama (Njujork, Čikago, Vašington). Smatralo se da je cilj formiranja ureda $\mathrm{u}$ velikim zapadnim centrima posledica nastojanja HNV-a da dalje legalizuje svoju aktivnost i pojača kontakt sa inostranim vlastima. Osim ureda, HNV je planiralo otvaranje kulturnih institucija u inostranstvu, pa je bilo najavljeno osnivanje „Kluba intelektualaca“, kao i obnavljanje „Matice hrvatske“. Ovako snažan start Hrvatskog narodnog vijeća impresionirao je pristalice ove nove emigrantske organizacije, koji se, stoji u dokumentu SID-a iz novembra 1982, „oduševljavaju tandemom Vidović-Meštrović, za koje kažu da su mladi intelektualci, sa vezama u establišmentu i sa dovoljno prodornosti i materijalnih sredstava za akcije HNV.“8

O registraciji predstavništva Hrvatskog narodnog vijeća u Francuskoj Služba za istraživanje i dokumentaciju Saveznog sekretarijata za inostrane poslove sastavila je krajem 1982. godine posebnu informaciju. Tu je navedeno da je ova filijala HNV-a u sredinom te godine u Francuskoj registrovana pod nazivom „Hrvatski nacionalni savjet - francuska sekcija (HNS)“. Ključnu ulogu u rukovodstvu Savjeta igrali su članovi nekadašnjeg „Mesnog odbora HNV-a Bruno Bušićc". Status Savjeta, prihvaćen od francuskih vlasti, pružao je, prema ocenama u SID-u, HNV-u „najšire mogućnosti“ za „legalno političko delovanje u Francuskoj“. U uvodnom delu statuta Savjeta istaknuto je da je njegov cilj „da na strogo legalan način širi istinu o hrvatskom narodu, njegovoj kulturi, istoriji, društvenom, političkom i ekonomskom položaju i da brani njegove interese“. Osim toga, Savjet je kao svoj zadatak proklamovao i informisanje Francuza o Hrvatskoj, te pružanje materijalne i pravne pomoći Hrvatima u Francuskoj. Bila je predviđena i podrška Hrvatima uhapšenim iz političkih razloga u Jugoslaviji. Prema podacima jugoslovenskih vlasti, na čelu Savjeta nalazilo se nekoliko

\footnotetext{
${ }^{7}$ Isto.

${ }^{8}$ AJ, 803-1782, Savezni savet za zaštitu ustavnog poretka (materijal za 6. sednicu Saveta), Noviji momenti u neprijateljskoj aktivnosti HNV-a, 16. novembar 1982.
} 
kvalifikovanih radnika, hrvatskih emigranata u Francuskoj, dok su iz pozadine ovom francuskom filijalom HNV-a upravljali ,Vidović i drugi“.9

U zaključku dokumenta SID-a o formiranju sekcije HNV-a podvučen je strah Beograda od etabliranja Hrvatskog narodnog vijeća u Parizu, i mogućnosti da takav realan uspeh ove organizacije hrvatskih političkih emigranata da vetar u jedra i drugim emigrantskim zajednicama iz Jugoslavije: „Po nas je nepovoljnije što je to (formiranje filijale $\mathrm{HNV}$-a - P. D.) učinjeno u Parizu, svetskom centru, i sa znatnom koncentracijom naših građana, što neće proći bez propagandnih efekata po emigraciju. “ ${ }^{10}$

Odricanje Hrvatskog narodnog vijeća od radikalizma u obračunu sa jugoslovenskim poretkom nije odobravano u ekstremnom hrvatskom emigrantskom miljeu. Radikalnim Hrvatima u egzilu smetale su i pozitivne percepcije vođstva HNV-a opozicionih, disidentskih krugova u samoj Hrvatskoj. Iz toga se izvodila teza o jugoslovenskoj orijentaciji ove organizacije početkom osamdesetih godina: ,Vidović i Meštrović trpe i dalje kritiku, posebno predstavnika ustaške emigracije (...), zbog toga što u nastojanju da oslobode HNV i Hrvatsku hipoteke ustaštva odriču ovome ideologiju i karakter narodnog pokreta. Vidovića i Meštrovića kritikuju i zbog poređenja situacije u Poljskoj i Jugoslaviji (...) što bi značilo da se i oni (Vidović i Meštrović - P. D.) bore za promenu komunističkog režima u Jugoslaviji, a ne i za NDH. Na toj liniji osporavaju i Vidovićeve kvalifikacije da su Tuđman, Gotovac i Veselica istaknute ličnosti hrvatskog pokreta. Proglašavaju Meštrovića i Vidovića za zagovornike treće Jugoslavije u čemu ih žele onemogućiti. “'11

Početak osamdesetih godina obeležilo je delovanje još jedne mlade hrvatske emigrantske organizacije. Tu organizaciju su osnovale grupacije koje su napustile Hrvatsko narodno vijeće posle Sabora HNV-a u Londonu 1980. godine, koji je doveo do pobede manje radikalne struje u Hrvatskom narodnom vijeću. Organizacija pod nazivom Hrvatski državotvorni pokret (HDP) bila je sastavljena od jednog krila Hrvatskog narodnog otpora i grupe okupljene oko Hrvatskog lista, koji su pokrenuli ,prolećari“" i njihov neformalni predvodnik Bruno Bušić 1978. godine. Za lidera HDP-a izabran je Nikola Štedul, koji će na čelu ove emigrantske organizacije ostati do kraja njenog postojanja. HDP je propagandno delovao preko pomenutog Hrvatskog lista, kao i na stranicama emigrantskih časopisa Pokret i Hrvatski tjednik. Krajem osamdesetih godina organizacija je, prema podacima jugoslovenskih policijskih organa, imala 29 filijala u Saveznoj Republici Nemačkoj (Keln, Manhajm, Frankfurt, Štutgart, Augsburg, Frajburg, Hamburg, Nirnberg, Karlsrue, Minhen, Zapadni Berlin), Švedskoj (Stokholm), Francuskoj (Pariz), Australiji (Melburn, Gelong, Gold Kost, Pert, Sidnej, Adeleid, Gipsland, Kanbera), Argentini (Buenos Ajres), Sje-

\footnotetext{
${ }^{9}$ AJ, 803-1782, Savezni savet za zaštitu ustavnog poretka (materijal za 6. sednicu Saveta), SSIP/SID, Informacija - Hrvatsko narodno vijeće registrovano u Francuskoj, 2. decembar 1982. ${ }^{10}$ Isto.

${ }^{11}$ AJ, 803-1782, Savezni savet za zaštitu ustavnog poretka (materijal za 6. sednicu Saveta), Noviji momenti u neprijateljskoj aktivnosti HNV-a, 16. novembar 1982.
} 
dinjenim Američkim Državama (San Hoze, Njujork, Čikago, Los Anđeles) i Kanadi (Hamilton, Toronto, Vankuver). ${ }^{12}$

Prema podacima iz knjige Mila Boškovića, Šesta kolona. Nastanak, organizacija i delovanje antijugoslovenske fašističke emigracije, ni lideri organizacije, kao ni većina članstva Hrvatskog državotvornog pokreta nisu bili pripadnici ustaškog pokreta, već se radilo, pre svega, o mlađoj emigrantskoj populaciji. Bošković navodi da je HDP pokušavao da „usmerava i organizuje celokupnu diverzantsko-terorističku aktivnost ustaške emigracije“, pri čemu se nastojalo da se težište ovih akcija prenese iz prekookeanskih zemalja u Zapadnu Evropu, i to pre svega u Saveznu Republiku Nemačku i Švedsku. ${ }^{13}$

Savezni sekretarijat za unutrašnje poslove je u elaboratu iz 1982. godine Hrvatski državotvorni pokret opisao kao organizaciju koja „okuplja najekstremniji deo ustaške emigracije“. Ova tvrdnja dopunjena je ocenom da je HDP orijentisan „na izvođenje subverzivno-propagandnih i diverzantsko-terorističkih akcija, sa težištem na izvođenje akcija u zemlji (gerilska dejstva, napadi na privredne objekte, paljevine itd.) ${ }^{614}$

Jugoslovenski policijski izvori svedoče da je HDP intenzivno distribuirao svoje propagandne materijale, ali da se značajno, kako ističe i Milo Bošković, usmerio i na nasilne akcije protiv jugoslovenskih interesa. To je koncizno tematizovano u elaboratu Službe državne bezbednosti Saveznog sekretarijata za unutrašnje poslove iz februara 1985. godine: „Rukovodstvo HDP je jula 1984. godine održalo u Škotskoj višednevni sastanak na kome su bili predstavnici iz više zapadnoevropskih i prekomorskih zemalja. Dogovoreno je da se intenzivira antijugoslovenska aktivnost, a posebno organizovanje diverzantsko-terorističkih akcija protiv SFRJ. U tu svrhu precizirane su metode delovanja i određena zaduženja pojedinaca (nabavka oružja, vrbovanje izvršilaca i sl.). Tokom avgusta 1984. formirani su novi ogranci HDP u SRN i Švedskoj, održano je više sastanaka, a u zemlju je prebačeno 40 kompletnih eksplozivnih naprava i izvesna količina oružja i propagandnog materijala. Na području SR Hrvatske SDB je otkrila neke veze terorista koje su raspolagale oružjem i opremom. Ovom akcijom SDB rasvetljeno je nekoliko slučajeva eksplozija i podmetanja mina na Jadranu i u unutrašnjosti zemlje iz 1982. i 1983. godine (...) U SR Nemačkoj borave, ili su boravili, neki istaknuti teroristi iz Australije i drugih zapadnih zemalja. To, i neka druga saznanja, ukazuju da je realno očekivati pokušaje izvođenja novih akcija HDP.“15

$\mathrm{U}$ istom dokumentu SDB je iznela i podatke o mogućoj promeni taktike Hrvatskog narodnog vijeća u borbi protiv Jugoslavije i njenog poretka. Istaknuto

${ }^{12}$ B. Vukušić, n. d., 81-92.

${ }^{13}$ Milo Bošković, Šesta kolona. Nastanak, organizacija i delovanje antijugoslovenske fašističke emigracije (Zagreb-Novi Sad: Dnevnik, 1985), 92-93.

${ }^{14}$ AJ, 803-1789, Savezni savet za zaštitu ustavnog poretka (materijal za 26. sednicu Saveta), Savezni sekretarijat za unutrašnje poslove - Osnovne karakteristike aktuelne bezbednosne situacije, 26. april 1982.

${ }^{15}$ AJ, 803-1793, Savezni savet za zaštitu ustavnog poretka (materijal za 11. sednicu Saveta), Savezni sekretarijat za unutrašnje poslove/Služba državne bezbednosti, 25. februar 1985. 
je da HNV ističe svoju opredeljenost za političke metode u konfrontaciji sa SFRJ, ali je navedena i odluka 5. sabora Hrvatskog narodnog vijeća na kojem je usvojena rezolucija koja je, prema tumačenjima analitičara Saveznog SUP-a, signalizirala „eventualnu promenu sredstava i metoda ove organizacije“. Radilo se o delu zaključnog dokumenta 5. sabora HNV-a, u kojem je bilo podvučeno da ,hrvatski narod ima pravo da u svojoj domovini revolucijom ostvari svoju narodnu slobodu i državnu nezavisnost". ${ }^{16}$ I tri godine pre ove procene SDB-a o okretanju HNV-a radikalnim metodama, Savezni SUP je u jednom elaboratu podvukao da, iako ova dominantna grupacija hrvatske političke emigracije deklarativno pledira za politička sredstva u svojoj kampanji protiv SFRJ, ona, ,ilegalno potpomaže i terorističke aktivnosti koje treba da doprinesu mobilizaciji ustaške emigracije“. ${ }^{17}$

$* * *$

Jugoslovenske bezbednosne službe su se posebno intenzivno bavile procenama o međunarodnim faktorima koji su stajali iza delovanja hrvatske političke emigracije. U fokusu je pre svega bila pozicija vodećih država Zapada, na prvom mestu Sjedinjenih Američkih Država, prema Hrvatima u egzilu i njihovim akcijama. Služba za istraživanje i dokumentaciju iznela je u analizi iz oktobra 1982. tezu da su iza formiranja i određivanja ciljeva Hrvatskog narodnog vijeća stajale obaveštajne službe zapadnih zemalja, pri čemu je posebno bila apostrofirana američka Centralna obaveštajna agencija (CIA). Radilo se, tvrdilo se u istom dokumentu, o nastojanju zapadnih službi da manipulišu ovom organizacijom ,u svom interesu“. Ocenjeno je i da strani faktor toleriše nenasilnu aktivnost hrvatske emigracije (propaganda, obraćanje međunarodnim organizacijama za zaštitu ljudskih prava), dok istovremeno sankcioniše terorističke poduhvate emigrantskih grupacija. Kao primer obračuna sa terorističkim aspektima emigrantskog delovanja navedena su sudska procesuiranja ekstremnih hrvatskih grupa u Australiji, SAD i Saveznoj Republici Nemačkoj. Potpora „stranog faktora“ aktivnostima HNV-a viđena je i u činjenici da su dotadašnji sabori ove organizacije bez smetnji održani u Torontu, Briselu i Londonu, uprkos „odlučnim“ " protestima jugoslovenskih vlasti. ${ }^{18}$

U dopuni ovog dokumenta SID-a istaknuto je da su SAD objedinjavanje organizacija hrvatske emigracije inicirale još krajem šezdesetih godina, da bi ta akcija bila intenzivirana početkom sedamdesetih godina i 1974. dovela do formiranja Hrvatskog narodnog vijeća, kao neke vrste krovne organizacije hrvatske političke emigracije. Značajna uloga u tom procesu pripisivana je hrvatskom katoličkom kleru u Sjedinjenim Američkim Državama, koji je, prema jugoslo-

16 Isto.

${ }^{17}$ AJ, 803-1789, Savezni savet za zaštitu ustavnog poretka (materijal za 26. sednicu Saveta), Savezni sekretarijat za unutrašnje poslove - Osnovne karakteristike aktuelne bezbednosne situacije, 26. april 1982.

18 AJ, 803-1782, Savezni savet za zaštitu ustavnog poretka (materijal za 6. sednicu Saveta), Savezni sekretarijat za inostrane poslove - Služba za istraživanje i dokumentaciju, Antijugoslovenska aktivnost tzv. Hrvatskog narodnog vijeća, 14. oktobar 1982. 
venskim izvorima, održavao kontakte sa visokim funkcionerima američke administracije. U pomenutom dokumentu konstatovano je da „HNV ima značajnu ulogu u strateškim planovima AOS (američke obaveštajne službe - P. D.) i drugih reakcionarnih krugova u SAD prema SFRJ i Balkanu uopšte, i služi im, pored ostalog, kao instrument pritiska na našu zemlju“. ${ }^{19} \mathrm{~S}$ tim u vezi, naglašeno je da je do ,puča“ u Hrvatskom narodnom vijeću i potiskivanja ekstremne frakcije na pomenutom saboru HNV-a u Londonu došlo upravo pod američkim uticajem. Istovremeno je izneta pretpostavka da je i Hrvatski državotvorni pokret ,iniciran iz istog centra kao i HNV“, iako je podvučeno da za takvu tvrdnju nema čvrstih dokaza. ${ }^{20}$

Za podršku delovanju hrvatske emigracije, odnosno Hrvatskog narodnog vijeća kao dominantne organizacije Hrvata u egzilu početkom osamdesetih godina, vlasti u Beogradu nisu optuživale samo Sjedinjene Države već i druge zapadne države u kojima su boravile velike hrvatske zajednice. U vezi sa registrovanjem filijale HNV-a u Francuskoj 1982. godine SID je posebno naglasio razočaranje zbog činjenice da je ovaj ustupak hrvatskoj emigraciji napravila levičarska, socijalistička vlada Francuske. Ova uprava Saveznog sekretarijata za inostrane poslove naglasila je potrebu protestovanja kod francuskih vlasti zbog konstituisanja predstavništva HNV-a. ${ }^{21}$

Jugoslovenski posmatrači prilika u hrvatskoj emigraciji registrovali su početkom osamdesetih godina brojne kontakte predstavnika Hrvatskog narodnog vijeća sa visokim zvaničnicima pojedinih zapadnih država. U dokumentu Službe Predsedništva SFRJ za pitanja zaštite ustavnog poretka, sastavljenom na osnovu informacija Saveznog sekretarijata za unutrašnje poslove i Službe za istraživanje i dokumentaciju Saveznog sekretarijata za inostrane poslove iz 1982. godine, navedeno je da je u toku provera informacije po kojoj se Mate Meštrović sa još nekolicinom lidera Hrvatskog narodnog vijeća sastao sa visokim funkcionerom Socijaldemokratske partije Nemačke (SPD) u Bonu, kao i da je Mirko Vidović kontaktirao sa neimenovanim uticajnim predstavnikom Socijaldemokratske partije Švedske. ${ }^{22}$

U pomenutom dokumentu posebna pažnja bila je posvećena kontaktima predstavnika HNV-a sa visokim zvaničnicima Kanade, pri čemu je podvučena činjenica da je Hrvatsko narodno vijeće osnovalo „mesni odbor“ u Otavi. Navedeno je pismo podrške šefa kanadske diplomatije predstavniku HNV-a Ivanu Žugeru, u kojem je ovaj član kanadske vlade podvukao da će se Otava založiti za poštovanje prava onih političkih zatvorenika u Jugoslaviji ,za koje se emi-

${ }^{19}$ AJ, 803-1782, Savezni savet za zaštitu ustavnog poretka (materijal za 6. sednicu Saveta), Mišljenja i sugestije uz informaciju SID-a SSIP-a (1982).

${ }^{20}$ Isto.

${ }^{21}$ AJ, 803-1782, Savezni savet za zaštitu ustavnog poretka (materijal za 6. sednicu Saveta), SSIP/SID, Informacija - Hrvatsko narodno vijeće registrovano u Francuskoj, 2. decembar 1982.

${ }^{22}$ AJ, 803-1782, Savezni savet za zaštitu ustavnog poretka (materijal za 6. sednicu Saveta), Noviji podaci o pojačanom kontaktiranju zvaničnih organa pojedinih zemalja sa neprijateljskom emigracijom jugoslovenskog porekla (1982). 
gracija bude zauzimala“. Podršku hrvatskoj političkoj emigraciji pružao je i gradonačelnik Toronta. Izneto je i da je 9. oktobra 1982. banketu upriličenom povodom otvaranja odbora u Otavi prisustvovao kanadski ministar industrije. U dokumentu je preneta i izjava Mirka Vidovića da će kanadsko ministarstvo kulture materijalno pomoći funkcionisanje odbora u Otavi sa 200.000 dolara godišnje. Kao indikator jasno pozitivnog stava kanadskih vlasti prema hrvatskoj političkoj emigraciji, tačnije prema HNV-u, u Beogradu je percipirano i odbijanje kanadskog ambasadora u Jugoslaviji da prihvati jugoslovenske „,kvalifikacije o terorističkom karakteru HNV-a“. U kontekstu simpatija kanadskog establišmenta prema hrvatskoj emigraciji ocenjivane su i izvesne mere kanadskih bezbednosnih organa prema jugoslovenskim predstavnicima u toj zemlji: „Učestali pritisci kanadske kontraobaveštajne policije (RCMP) na naše diplomatskokonzularne predstavnike ukazuju da se ustaškoj emigraciji od strane nadležnih kanadskih organa stvara širi prostor za antijugoslovensko delovanje." Zaključujući ovaj pregled izneta je teza da svi podaci o spoljnoj podršci delovanju hrvatske političke emigracije imaju ,posebnu težinu“, odnosno da dolaze „u vreme naših (jugoslovenskih - P. D.) teškoća“, te da se uklapaju u „Reganovu antikomunističku kampanju“. ${ }^{23}$

Hrvatska emigracija nije komunicirala isključivo sa političkim i bezbednosnim centrima na Zapadu. Početkom osamdesetih godina u Jugoslaviji su registrovana i koketiranja Hrvata $u$ egzilu sa drugim, nezapadnim, delovima sveta. U cilju dobijanja podrške i od islamskog sveta HNV je osnovala posebnu sekciju zaduženu za povezivanje sa muslimanskim zemljama. Na čelu ovog „Ureda“ nalazio se Kerim Reis, ustaški veteran koji se deklarisao kao muslimanski Hrvat. Reis je, prema jugoslovenskim obaveštajnim podacima, prisustvovao proslavi trogodišnjice islamske revolucije u Teheranu. Osim toga, HNV je nastojalo da sa Iranom uspostavi kontakt i preko iranskog diplomatskokonzularnog predstavništva u Briselu. Hrvatska emigracija je težila da saradnju sa islamskim svetom iskoristi za dobijanje podrške ,na antikomunističkoj i panislamskoj osnovi“. Do Beograda su došle i (neproverene) informacije o spremnosti Moamera el Gadafija da materijalno pomogne hrvatsku političku emigraciju, ali je ona tu pomoć odbijala strepeći od moguće „kompromitacije pred Zapadom“. 24

Hrvatski državotvorni pokret je, prema saznanjima Beograda, takođe preduzimao ekstravagantne spoljnopolitičke izlete. Tako je, prema jugoslovenskim ocenama, kontaktima sa oslobodilačkim pokretima (IRA, PLO, El Salvador), i levičarskim partijama HDP nastojao da se predstavi kao snaga koja ,izražava progresivne težnje savremenog čovečanstva““. ${ }^{25}$

23 Isto.

${ }^{24}$ AJ, 803-1782, Savezni savet za zaštitu ustavnog poretka (materijal za 6. sednicu Saveta), Savezni sekretarijat za inostrane poslove - Služba za istraživanje i dokumentaciju, Antijugoslovenska aktivnost tzv. Hrvatskog narodnog vijeća, 14. oktobar 1982.

${ }^{25}$ AJ, 803-1782, Savezni savet za zaštitu ustavnog poretka (materijal za 6. sednicu Saveta), Noviji podaci o pojačanom kontaktiranju zvaničnih organa pojedinih zemalja sa neprijateljskom emigracijom jugoslovenskog porekla (1982). 
Jugoslovenske posmatrače prilika $u$ hrvatskoj emigraciji posebno su brinuli kontakti sa istočnom stranom hladnoratovskog sveta. Radilo se, pre svega, o vezama koje je lider HNV-a Mate Meštrović početkom osamdesetih godina ostvario u Bugarskoj. Meštrovićevo prisustvo na proslavi 1.300 godina bugarske državnosti uznemirilo je Beograd i unelo dodatne tenzije u inače zategnute odnose Jugoslavije i Bugarske krajem sedamdesetih i početkom osamdesetih godina. ${ }^{26}$ Meštroviću je poziv uručen zvaničnim putem, preko bugarskog konzula u Torontu, a u ime Bugarske akademije nauka. Sam Meštrović je smatrao da je u Sofiju pozvan na inicijativu Ljudmile Živkov, uticajne ćerke Todora Živkova i pokroviteljke proslave pomenutog jubileja. Lider HNV-a je, zaključujemo na osnovu njegove knjige, poziv prihvatio sa zadovoljstvom, prisećajući se već tradicionalne hrvatsko-bugarske bliskosti: „Uostalom, mi smo Hrvati u Bugarima odvajkada vidjeli saveznike, držeći se nauka iz staroga Rima da je neprijatelj moga neprijatelja - moj prijatelj. “27

Meštrović je u Sofiji, čitamo u njegovoj knjizi, bio primljen na visokom nivou. Tvrdio je da je upoznao čitav državni i partijski establišment, te da je na njega poseban utisak ostavio ministar odbrane, general Dobri Đurov. Upoznao je i Venka Markovskog, makedonskog/jugoslovenskog emigranta u Bugarskoj, koji je tada bio, isticao je Meštrović, bugarska ,živa zvijezda u službi partije, države i armije". Poseban pečat boravku prominentnog hrvatskog emigranta u Bugarskoj dao je njegov nastup na bugarskoj televiziji, odnosno njegov intervju sa Aksinijom (u Meštrovićevoj knjizi pogrešno stoji „Ksenijom“) Đurovom, ćerkom već pomenutog bugarskog generala. Od Meštrovića je, pri tom, traženo da kaže „koje slovo o dugome prijateljstvu hrvatskoga i bugarskoga naroda“. Poseban eho ove posete lidera HNV-a Bugarskoj predstavljao je pogovor Meštrovića u knjizi Venka Markovskog o Golom otoku The Island of Death, objavljenoj u SAD ubrzo posle Meštrovićevog boravka u Sofiji. Prema Meštrovićevom svedočenju, bugarske vlasti su i u kasnijem periodu ostale u "diskretnom“ kontaktu sa liderom najveće hrvatske emigrantske organizacije. Kao primer navedeni su pozivi Meštroviću na bugarsko-američke seminare u Njujorku i Torontu. $^{28}$

Boravak važnog čoveka hrvatskog emigrantskog miljea u Bugarskoj izazvao je burne reakcije u Jugoslaviji. Meštrović u svojoj knjizi navodi da je tim povodom jugoslovenski Savezni sekretarijat za inostrane poslove protestovao kod bugarske ambasade u Beogradu, a protestovalo se i u Moskvi, tražeći da „Sovjeti svojim autoritetom obuzdaju bugarske veze sa hrvatskom fašističkom emigracijom“. Meštrović je isticao da Beograd nije isključivao mogućnost da iza bugarskih kontakata sa hrvatskom emigracijom stoje Sovjeti. To pitanje postavljao je sebi i sam Meštrović, pitajući se da li je bugarski poziv njemu na

\footnotetext{
${ }^{26} \mathrm{O}$ odnosima Jugoslavije i Bugarske neposredno pre i posle smrti Josipa Broza Tita detaljnije u: Petar Dragišić i Olivera Dragišić, Jugoslavija i Bugarska 1944-1980: hronika neuspešnog prijateljstva (Beograd: Institut za noviju istoriju Srbije, 2019).

${ }^{27}$ M. Meštrović, $n$. d., 130-132.

${ }^{28}$ Isto, $134-142$.
} 
proslavu 1.300 godina bugarske državnosti bio odobren od Moskve, te da li je to signaliziralo promenu sovjetske pozicije prema režimu u Beogradu: „Pitao sam se: je li Moskva blagoslovila da me Bugari zovnu na svoju nacionalnu feštu, na kojoj su okupili značajne ličnosti sa svih kontinenata? Je li to odmak Istoka u politici prema Beogradu i Titu, koja se od Rezolucije Informbiroa 1948. godine vrtoglavo obrtala od vrućega prema hladnome i obratno? Znao sam da je Staljin u nekim trenucima, uoči početka Drugoga svjetskoga rata, bio vrlo sklon komadanju Jugoslavije (...)". ${ }^{29}$ Prema Meštrovićevom svedočenju u intervjuu za bugarski list Trud marta 1998. godine, Sovjeti su posle jugoslovenskih pritužbi izvršili pritisak na Sofiju da prekine veze sa hrvatskom emigracijom. ${ }^{30} \mathrm{O}$ jugoslovenskom diplomatskom protestu upućenom Sofiji saznajemo i u jednom dokumentu bugarske ambasade u Beogradu iz aprila 1982. godine. Tu se, između ostalog, kaže da je povodom posete Mate Meštrovića Bugarskoj Savezni sekretarijat za inostrane poslove protestovao kod bugarskih vlasti, te da je SSIP instruirao jugoslovenske medije da pokrenu kampanju u kojoj se Bugarskoj prebacivala ,,saradnja sa ustašama“ ${ }^{31}$

Hrvatska emigracija je komunicirala ne samo sa pojedinim državama $\mathrm{i}$ njihovim bezbednosnim sistemima, već i sa drugim jugoslovenskim emigrantskim grupacijama. Saradnja je posebno bila razvijena sa albanskom političkom emigracijom. U elaboratu Saveznog sekretarijata za unutrašnje poslove iz 1976. godine primećeno je da hrvatska politička emigracija u organizovanje nasilnih akcija nastoji da uključi i ,pojedine ekstremiste iz redova albanske i makedonske neprijateljske emigracije“" ${ }^{32}$ Maja 1979. godine u analizi Saveznog sekretarijata za inostrane poslove konstatovano je da Hrvatsko narodno vijeće insistira na ,jačanju veza sa albanskom emigracijom“, te da HNV od Hrvata traži da materijalno pomognu aktivnosti albanske političke emigracije. ${ }^{33}$

Konkretne posledice nastojanja hrvatske emigracije da ostvari dublju saradnju sa albanskom političkom emigracijom bile su demonstracije hrvatskih i albanskih emigranata povodom ,kontrarevolucije“ na Kosovu u proleće 1981. godine. Zajednički protesti organizovani su u nekoliko velikih centara. Demonstranti su u Parizu nosili zastave Velike Albanije i Nezavisne Države Hrvatske, dok se u Frankfurtu protestovalo protiv, kako se isticalo, represivnih postupaka nad Hrvatima i kosovskim Albancima u SFRJ. ${ }^{34}$ U Njujorku su albanski demon-

${ }^{29}$ Isto, 131-137.

30 „Белград бързаше да се оплаква в Москва от София“, Труд, 15. 3. 1998.

31 Македонският въпрос в българо-югославските отношения 1968-1989, част 2 (София: Държавна агенция „Архиви“, 2012), 188.

32 AJ, 803-1781, Savezni savet za zaštitu ustavnog poretka (materijal za 16. sednicu Saveta), Savezni sekretarijat za unutrašnje poslove, Procena neprijateljskih snaga koje deluju protiv SFRJ (peta i šesta kolona), jun 1976.

33 AJ, 803-1785, Savezni savet za zaštitu ustavnog poretka (materijal za 16. sednicu Saveta), Savezni sekretarijat za inostrane poslove, Psihološko-subverzivna propaganda protiv SFRJ i borba protiv nje, 4. maj 1979.

34 Petar Ristanović, „Srpska intelektualna elita i kosovsko pitanje 1974-1989“, doktorska disertacija, Univerzitet u Beogradu, Filozofski fakultet, Odeljenje za istoriju, 2018, 262. 
stranti izvikivali parole o ,slobodi Hrvatske“, dok je protestu Albanaca u Vašingtonu prisustvovalo oko 20 hrvatskih političkih emigranata, uključujući i funkcionera HNV-a Hrvoja Luna. U dokumentu Saveznog sekretarijata za inostrane poslove iz aprila 1981. konstatovano je da je većina organizacija hrvatskih političkih emigranata iskazala ,solidarnost" demonstrirajući sa albanskom emigracijom u vezi sa događajima na Kosovu. ${ }^{35}$ Aprila 1982. Savezni SUP je u elaboratu „Osnovne karakteristike aktuelne bezbednosne situacije“ izneo podatak da „ustaška i albanska emigracija zajednički vrše pripreme terorističkih akcija, za koje bi ustaška obezbedila oružje, a albanska izvršioce“. ${ }^{36}$ Septembra 1982. na sednici Saveznog saveta za zaštitu ustavnog poretka konstatovano je „dalje povezivanje ustaške i albanske emigracije“، 37

$* * *$

$\mathrm{Na}$ prethodnim stranama već smo ukazali na činjenicu da se hrvatska politička emigracija, koja se početkom osamdesetih godina prošlog veka okupljala pre svega oko Hrvatskog narodnog vijeća i Hrvatskog državotvornog pokreta, sve intenzivnije fokusirala na politička sredstva borbe protiv Jugoslavije, pri čemu nisu napuštane ni radikalne metode u obračunu sa jugoslovenskim poretkom. Terorističke udare protiv jugoslovenskih interesa sprovodio je pre svega Hrvatski državotvorni pokret. Ipak, u poređenju sa periodom krajem šezdesetih i početkom sedamdesetih godina žestina nasilnih udara hrvatske emigracije na Jugoslaviju početkom osamdesetih godina bila je osetno smanjena. U tom periodu nisu zabeležena drastična dela, poput ubistva jugoslovenskog ambasadora, bombaškog napada u bioskopu „,20. oktobar“, ili upada Bugojanske grupe u Jugoslaviju. Nasilni akti hrvatske političke emigracije početkom osamdesetih godina bili su, dakle, manje intenzivni i radikalni nego u prethodnom periodu, a primetno je bilo nastojanje da se akcije izvode na jugoslovenskom tlu. Od početka 1981. godine do kraja 1983. registrovano je više terorističkih akata u Jugoslaviji, i to pre svega na hrvatskom primorju. Jula 1982. podmetnut je eksploziv u restoranu „Smokva“ na ostrvu Pag, prilikom čega su povređene dve osobe, a pričinjena je i materijalna šteta, da bi nekoliko dana kasnije došlo do detonacije u restoranu „Galeb“ u Rijeci, koja je dovela do povređivanja tri lica. Avgusta i septembra iste godine zabeležene su eksplozije u dva turistička objekta u Šibeniku, odnosno u Zadru. Avgusta 1982. registrovan je neuspešan bombaški napad ispred zgrade opštine Novi Beograd. Do eksplozije nije došlo usled kvara na satnom mehanizmu. Naredne godine na udaru je bila Slavonija. Aprila 1983. aktivirana je eksplozivna naprava ispred prodavnice „Lasta“ $\mathrm{u}$ Vinkovcima, a krajem decembra iste godine izazvana je eksplozija na železnič-

${ }^{35}$ AJ, 803-101, 73. sednica Predsedništva SFRJ, 8. maj 1981, Savezni sekretarijat za inostrane poslove, Informacija, 27. april 1981.

${ }^{36}$ AJ, 803-1789, Savezni savet za zaštitu ustavnog poretka (materijal za 26. sednicu Saveta), Savezni sekretarijat za unutrašnje poslove - Osnovne karakteristike aktuelne bezbednosne situacije, 26. april 1982.

${ }^{37}$ AJ, 803-1789, Savezni savet za zaštitu ustavnog poretka (materijal za 4. sednicu Saveta), Rezime rasprave o aktuelnoj bezbednosnoj situaciji, 16. septembar 1982. 
koj stanici u istom gradu, koja je izazvala materijalnu štetu. Avgusta iste godine podmetnuta je bomba na benzinskoj pumpi u Slavonskom Brodu. Početkom osamdesetih zabeleženi su i napadi na različita jugoslovenska predstavništva u inostranstvu (turističke agencije, ,Geneks“'). Sve ove akcije jugoslovenska policija je pripisivala Hrvatskom državotvornom pokretu. ${ }^{38}$

Početkom 1985. godine Savezni sekretarijat za unutrašnje poslove konstatovao je da je cilj hrvatske političke emigracije prebacivanje terorističkih akcija u samu zemlju. Izneto je da je tokom 1983. i 1984. godine hrvatska emigracija u inostranstvu izvela 16 ,manjih provokativnih akcija“, kao i da je ubijen jedan Jugosloven, za koga je emigracija pretpostavljala da je saradnik jugoslovenske tajne policije. Radilo se o primetnom slabljenju intenziteta nasilnih akcija hrvatske emigracije u inostranstvu, budući da je u 1982. godini izvan granica Jugoslavije izvršeno čak 40 antijugoslovenskih diverzantskih akata. Upravo ti podaci naveli su analitičare Saveznog SUP-a da procene da će se emigracija intenzivnije usredsrediti na akcije u samoj Jugoslaviji, o čemu je u elaboratu SSUP-a izneto više detalja: „Terorističke organizacije i grupe ustaške emigracije čija su najsnažnija žarišta i dalje u SR Nemačkoj, zatim u Francuskoj, Švedskoj i Australiji, a centralna rukovodstva u SAD i Australiji, svoju aktivnost su i 1983. i 1984. godine usmerile na organizovanje i izvođenje terorističkih akcija u zemlji. Glavni cilj ovih aktivnosti bio je ugrožavanje i ometanje ZOI 84 (Zimskih olimpijskih igara u Sarajevu - P. D.) i turističke sezone. Planirane su i pripremane akcije na hotele, restorane, saobraćajnice, prevozna sredstva i druge vitalne objekte, i to ne samo na područjima odvijanja ZOI 84 i jadranskoj obali, već i na širem prostoru zemlje. Cilj takve njihove orijentacije bio je da se kod domaće i međunarodne javnosti stvori utisak o postojanju snaga otpora u zemlji, a emigracija i neprijateljske strukture u zemlji podstaknu na delovanje protiv ustavnog poretka. Za izvođenje ovakvih akcija ustaška emigracija je raspolagala i raspolaže određenim količinama oružja, eksploziva i drugog diverzantskog materijala, i stalno radi na nabavci novih količina, a za izvršioce vrbuje naše građane privremeno zaposlene $u$ inostranstvu (...) Emigracija je $u$ 1983. i 1984. godini u zemlji izvršila samo nekoliko manjih diverzija, bez teških posledica.“39

Uz navođenje činjenice da 1983. i 1984. godine hrvatska emigracija u zemlji nije izvela relevantniju nasilnu akciju, SSUP je u pomenutom dokumentu naveo $\mathrm{i}$ neke bitnije rezultate $\mathrm{u}$ borbi jugoslovenskog bezbednosnog aparata protiv hrvatske ekstremne emigracije. U pomenutom periodu SDB je od grupacija hrvatske emigracije oduzela (ili uništila) oko 150 kilograma eksploziva, kao i manje količine naoružanja i municije, namenjene akcijama u Jugoslaviji. Osim toga, jugoslovenske vlasti su uhapsile 24, a osudile 19 osoba „koje su iz inos-

\footnotetext{
${ }^{38}$ Ljiljana Bulatović i Božidar Spasić, Smrt je njihov zanat: dokumenti ustaškog terorizma (Beograd: Politika, 1993), 104-106.

39 AJ, 803-1793, Savezni savet za zaštitu ustavnog poretka (materijal za 11. sednicu Saveta), Savezni sekretarijat za unutrašnje poslove/Služba državne bezbednosti, 25. februar 1985.
} 
transtva dolazile $\mathrm{u}$ zemlju po zadacima terorističkih grupa, ili u zemlji bile njihove veze“. ${ }^{40}$

Jugoslovenske bezbednosne agencije su u borbi protiv hrvatskih emigrantskih grupacija preduzimale i najradikalnije akcije. Prema navodima u knjizi Bože Vukušića jugoslovenske tajne službe su od 1946. do 1990. godine fizički eliminisale 69 hrvatskih političkih emigranata. Od 1981. do 1984. godine je, prema Vukušićevim navodima, ubijeno 12 hrvatskih emigranata. ${ }^{41}$ Svakako, najviše pažnje je tada, a i u godinama i decenijama koje su usledile, privukao atentat na Stjepana Đurekovića, koji je bio predmet nebrojenih žurnalističkih i publicističkih tematizacija, ali je na kraju dobio i sudski epilog u procesu protiv visokih funkcionera Službe državne bezbednosti SR Hrvatske, Josipa Perkovića i Zdravka Mustača. ${ }^{42}$

Akcije jugoslovenskog režima nisu dovele do uništenja hrvatske političke emigracije. Početkom osamdesetih godina ona se temeljno reorganizovala, grupišući se u dve velike organizacije (HNV i HDP), stavila snažniji akcenat na političke forme delovanja (bez potpunog odustajanja od nasilnih metoda) i ostvarila veze sa brojnim faktorima na Zapadu, ali i na Istoku. Strpljivo je čekala i dočekala svojih ,,pet minuta“, kada je raspadom istočnoevropskih sistema uspela da se trijumfalno vrati u SFRJ/Hrvatsku i aktivno učestvuje u dramatičnim borbama za hrvatsko izdvajanje iz Jugoslavije.

40 Isto.

41 B. Vukušić, n. d., 217-220.

42 „Perkoviću kazna od 30 godina, izručenje u roku od mjesec dana“, Večernji list, 14. 12. 2018; „Zdravku Mustaču 40 godina zbog ubojstva Stjepana Đurekovića“, Večernji list, 25. april 2019. Opis jedne verzije operacije „Dunav“ nalazimo u memoarskoj knjizi Božidara Spasića: Lasica koja govori: osnovne pretpostavke borbe protiv terorizma (Beograd: autor, 2000), 77-86. 


\section{REFERENCE}

- Bošković, Milo. Šesta kolona. Nastanak, organizacija $i$ delovanje antijugoslovenske fašističke emigracije. Zagreb-Novi Sad: Dnevnik, 1985.

- Bulatović Ljiljana, i Božidar Spasić. Smrt je njihov zanat: dokumenti ustaškog terorizma, Beograd: Politika, 1993.

- Cvetković, Srđan. „Terorizam i jugoslovenska politička emigracija“. Istorija 20. veka, br. 2, (2014), 171-197. https://doi.org/10.29362/ist20veka.2014.2.cve.171-198

- Dimitrijević, Bojan. „Istorijski aspekti terorizma u Srbiji“. Istorija 20. veka, br. 1, (2008), 131-140.

- Dragišić, Petar. "Operation Phoenix in Yugoslavia in the Summer of 1972 and Yugoslav-Austrian Relations". Tokovi istorije, br. 3, (2018), 87-106. https://doi.org/10.31212/tokovi.2018.3.dra.87-106

- Dragišić Petar, i Olivera Dragišić. Jugoslavija i Bugarska 1944-1980: hronika neuspešnog prijateljstva. Beograd: Institut za noviju istoriju Srbije, 2019.

- Dragišić, Petar. Ko je pucao u Jugoslaviju? Jugoslovenska politička emigracija 1968-1980. Beograd: Institut za noviju istoriju Srbije, 2019.

- Jareb, Mario. „Hrvatska politička emigracija 1928-1990“. U: Hrvatska politika u XX stoljeću. Ur. Ljubomir Antić, 307-336. Zagreb: Matica hrvatska, 2006.

- Kalabić, Radovan. Srpska emigracija. Prilozi za istoriju srpskog iseljeništva (1830-1992) - drugo, dopunjeno izdanje. Beograd/Njujork: b. i., 1995.

- Makedonskijat v"pros v b"lgaro-jugoslavskite otnoshenija 1968-1989, chast 2. Sofija: D"rzhavna agencija „Arhivi“, 2012.

- Meštrović, Mate. U vrtlogu hrvatske politike. Kazivanje Peri Zlataru. Zagreb: Golden marketing, 2003.

- Pavlica, Branko. Antijugoslovenska aktivnost neprijateljske emigracije u SR Nemačkoj (1951-1984). Smederevo: Naš glas, 1990.

- Ristanović, Petar. „Srpska intelektualna elita i kosovsko pitanje 1974-1989“. Doktorska disertacija, Univerzitet u Beogradu, Filozofski fakultet, Odeljenje za istoriju, 2018.

- Spasić, Božidar. Lasica koja govori: osnovne pretpostavke borbe protiv terorizma. Beograd: autor, 2000.

- Vukušić, Bože. Tajni rat UDBE protiv hrvatskoga iseljeništva. Zagreb: Klub hrvatskih povratnika iz iseljeništva, 2001. 
PETAR DRAGIŠIĆ, PhD, Senior Research Associate

Institute for Recent History of Serbia

Belgrade, Republic of Serbia

petar.dragisic@gmail.com

\section{CROATIAN POLITICAL EMIGRATION AND YUGOSLAVIA \\ IN THE EARLY 1980s. PREPARATIONS FOR THE FINAL CLASH}

\section{Summary}

From the end of World War II to the dissolution of Yugoslavia, Yugoslav political emigrants were in permanent conflict with the Yugoslav socialist system. Particularly active in the fight against their homeland were Croatian émigrés, who, in this peculiar, unconventional warfare, used not only propaganda, but also resorted to violence.

In the early 1980s the most influential Croatian émigré organizations were Hrvatsko narodno vijeće/Croatian National Council (HNV) and Hrvatski državotvorni pokret/Croatian Statehood Movement (HDP). While the Croatian National Council in its campaigns against Yugoslavia used chiefly political and propaganda tools, the Croatian Statehood Movement gave priority to violent methods. In comparison to the 1960s and the 1970s the terrorist activities of Croatian émigrés in the 1980s decreased in intensity. According to Yugoslav sources, in the last decade of Yugoslavia's existence the Croatian émigrés focused their terrorist activities on targets on Yugoslav soil. In this life-and-death struggle the Yugoslav regime did not refrain from using the most radical methods. Nevertheless, the Croatian émigré organizations outlived socialist Yugoslavia and took active part in the wars of Yugoslav succession in the 1990s.

KEYWORDS: Croats, Emigration, Croatian National Council, Mate Meštrović, Yugoslavia 